\title{
An Empirical Study on the Timing of Big Retailers' Initial Internationalization: Influence of the Target Market and Entry-Mode Choice
}

(C) Higher Education Press and Springer-Verlag 2010

\begin{abstract}
This paper examines the timing of big retailers' initial internationalization and proposes a theoretical framework. Then, the framework is tested with the proportional hazard model and data of European and U.S. big retailers. Empirical results show that retailers' entry timing is jointly influenced by the economic conditions of both the home market and target foreign markets, cultural and geographical distance, and the entry mode. Based on these findings, this article offers suggestions to China's big retailers whose initial internationalization has just started.
\end{abstract}

Keywords big retailers, initial internationalization timing, target market, entry mode

\section{Introduction}

The rapid globalization of economic activities has provided opportunities for marketing of goods and services abroad (Douglas and Craig, 1995). As foreign markets become increasingly important, firms have to invest substantial financial and managerial resources in the international markets. The required investment is higher for those whose internationalization has just started. Therefore, the initial internationalization decisions, such as when, where and how to enter a foreign

Translated from Zhongguo Ruankexue 中国软科学 (China Soft Science), 2009, (1): 97-111

Rongsheng Cai

School of Business, Renmin University of China, Beijing 100872, China

E-mail: cairongsheng@263.net

Yong Wang ( $\square)$

School of Business, Beijing Technology and Business University, Beijing 100048, China

E-mail: rucwy@sohu.com 
market, are becoming parts of companies' strategy mix to regain competitiveness and relocate their resources (Terpstra and Sarathy, 1994).

Compared to manufacturing firms, many firms from the service industry are relatively new to international markets. As a part of the service sector, most retailers carried out their internationalization even more recently. Some of the biggest retailers, such as Wal-Mart, Home Deport and Best Buy, have just begun to cross the national borders of their home countries over the past 10 years. Now, an increasing number of big retailers are facing the initial internationalization decisions. However, not all retailers went abroad achieved good performance. Some succeeded, while many others failed and retreated from foreign markets.

The extant literature on internationalization strategy also has many limitations: first of all, most of the existing studies are limited to manufacturing firms, and little attention has been paid to service firms, especially for retailers. Secondly, most of the prior studies only describes and summarizes the methods, motivation, outcome, and efficiency of the internationalization (Kim and Hwang, 1992; Woodcock, Paul and Shige 1994; Madhok, 1997), and there has been little empirical research on firms' important initial internationalization decision (Mitra and Golder, 2002). Thirdly, in the prior research on firm's initial internationalization, the foreign market choice, entry methods, and entry timing were discussed in isolation, and main attention was paid to the first two issues, neglecting to a large extent, the timing of entry (Sivakumar, 2002). In fact, these three issues are closely related to each other. In particular, as a firm's important turning point in the transition from domestic operation to international operation, the timing of entry is part of its internalization decision based on consideration of the influence of foreign market factors and various means of internationalization.

To address the limitations identified in the previous paragraph, this article focuses on firms in service sectors (i.e., big retailers) and discusses their initial internationalization decisions. By investigating why a big retailer enters a specific foreign market at a specific time with a specific method, we can get a deeper understanding of the mode of firms' initial internationalization decision. On the basis of extant research, this paper examines the timing of big retailers' initial internationalization and proposes a comprehensive theoretical framework. It is tested by using the proportional hazard model and the data of the European and U.S. retailers.

The model proposed in this paper has implications for big retailers facing the initial internationalization decision: It can both serve as a framework for retailers' internationalization policy, and provide reference indexes of macro environment to help retailers make their initial internationalization decision. As most of the retailers considering foreign markets for the first time face tight supply of resources, information and social capital, these macro indexes are of reference significance for them in making important initial internationalization decisions 
(Bell, 1997; Coviello, 2006; Ojala and Tyrvainen, 2007).

\section{Literature Review}

A variety of theories have been proposed concerning retailers' initial internationalization, such as retailers' motivation for internationalization, organizational learning theory, and first-mover advantage theory. Each theory is characterized by its own insightful findings. Below, we will briefly introduce some of these important theories:

\subsection{The Motivation for Retailers' Internationalization}

In the extant literature, three factors have been identified to motivate a retailer's internationalization, namely the pulling, pushing, and facilitating factors (Wrigley and Lowe, 2002).

Researchers pointed out that limited home market size and fierce domestic competition would push retailers to cross the border to find more opportunities abroad. Meanwhile, as most of the international retailers rely heavily on their home markets (GPN, 2003), a large home market can provide them with more resources and experience to launch high-risk oversea operations, while a small home market limits retailers' resource commitment and risk resistance (Bell, McNaughton, Young and Crick, 2003; Spence, 2003). Therefore, the condition of home market directly affects retailers' internationalization decision and their internationalization strategies.

Other researchers proposed that foreign markets have pulling effects on retailers' internationalization. The pulling factors include all the attributes that make a particular foreign market attractive. For example, a report by the Chain Store Age (1997) found a series of these "pulling" factors in its exploration of the main factors considered by retailers when choosing a target market, including its macro economy conditions, national environment in terms of the social and political background, market risks and competition, customers' demand, technical feasibility, distribution structures, supplier base, market forecasts, relevant regulation, and taxation. Therefore, the condition of foreign markets also affects retailers' internationalization strategy and behavior.

Some pointed out that the external environment (both at home and abroad) interplay with a retailer's internal factors in jointly influencing the retailer's internationalization decision (McGoldrick and Davies, 1995). Retailers made their international decision after a comprehensive assessment of the conditions in the home and foreign markets and internal factors. 


\subsection{An Integrated Framework of Firms Internationalization}

Dunning (1988) synthesized different theories and empirical findings on retailers' internationalization. He proposed an integrated framework consisting of the ownership of a firm, advantages of its international operations, and location advantages of countries. This framework has been applied to explaining firms' internationalization timing and approach, and has been expanded with variables such as business strategy and competitive environment in subsequent research (e.g., Hill, Hwang and Kim 1990; Kim and Hwang, 1992).

As for the mode of a firm's internationalization, some researchers pointed out that the entry mode chosen by firms is significantly related to their strategic objectives, organizational features, and international market conditions and competition (Agarwal and Ramaswami, 1992; Anderson and Gatignon, 1986; Ekeledo and Sivakumar, 1998). Different entry modes imply different levels of resource commitment, risk, reward, cost, and control (Tersptra and Sarathy, 1994). Gaba, Pan and Ungson (2002) classified entry mode into equity-based (i.e., equity joint ventures and wholly owned subsidiaries) and non-equity-based (i.e., exporting and licensing). He proposed that, the equity-based mode requires on-going decision-making and management of the firms, and investment in assets is often irreversible. In contrast, the non-equity mode is based on specific contracts, and the level of risk tended to be lower than that of in the equity-based mode.

Some researchers analyzed the relationship between the timing and mode of firms' internationalization. They identified that the timing and mode of entry are closely related to one another (Mascarenhas, 1992; Madhok, 1997). Buckley and Casson (1981) analyzed different entry timing and modes. They found that the optimal timing and mode can significantly reduce a firm's internationalization cost, and expand the firm's resources by making full use of the growth in the international market.

\subsection{Organizational Learning in the International Market}

Theories of organizational learning argue that firms develop knowledge based on their experiences. This repository of knowledge constitutes an important resource of firms, and is a source of competitive advantage (Diericks, Cool and Barney, 1989; Lippman and Rumelt, 1982). Operating in international market is also an organizational learning and knowledge accumulation progress. Particularly, for firms that enter international markets for the fist time, the knowledge learned from the home market significantly influences their initial internationalization decisions (Barkema, Bell and Pennings, 1996; Leonidou and Katsikeas, 1996; Barkema and Vermeulen, 1998). Therefore, firms going for internationalization 
usually choose to enter familiar markets first because these markets have smaller cultural and geographical distance.

Organizational learning in the international market has been tested by later empirical research. Researchers have found that cultural and geographical distance play a significant role in a firm's initial internationalization, and market factors influence a firm's subsequent internationalization decisions (Moen, Gavlen and Endressen, 2004; Jones and Covilllo, 2005; Ojala and Tyrvainen, 2007).

\subsection{First-Mover Advantages in the International Market}

From the perspective of first-mover advantage, researchers initially focused on the entry timing in the domestic market and its advantages. They found that the order of entry was significantly related to competitive strategy and performance (Kerin, Varadarajan and Peterson, 1992; Lieberman and Montgomery, 1988; Szymanski, Troy and Bharadwaj, 1995).

Then, researchers expanded the first-mover advantage theory from the domestic market to the international market (Buckley and Casson, 1981). They found that early entry into the international market could provide firms with more opportunities to become the leaders in product and technology market. Meanwhile, moving into an alien market early could also incur higher entry costs and transaction risks, while the followers could reduce these costs and risks by learning from the early entries.

In the early empirical research on first-mover advantages, entry timing was measured by the order of entry into the international market, and firms were classified into three categories, namely first movers, early followers, and late entrants (Lieberman and Montgomery, 1998). Luo (1998) argued that the categorical approach is effective in analyzing an oligopolistic market, where first movers and followers could be defined clearly. However, this approach has many problems in analyzing industries characterized by intensified competition where many firms can be called first movers, even though there are great differences in their actual entry time. He therefore recommended the use of actual time of entry as a more accurate measure. Sivakumar (2002) argued that the order of entry is an intra-firm variable, yet the time of entry could have both intra-firm and inter-firm implications.

Moreover, some researchers also found that the first mover's advantages are not isolated, but influenced by the attributes of a firm itself, its market, and the environment (Szymanski et al., 1995).

\section{The Conceptual Framework and Hypotheses}

Based on the above literature review, we conclude that the timing of initial 
internationalization significantly affects a firm's performance and position in a new market. We therefore focus on the timing of big retailers' initial internationalization, and try to figure out the influence that the foreign market condition and entry method choice have on the timing. We develop a theoretical framework as Fig. 1:

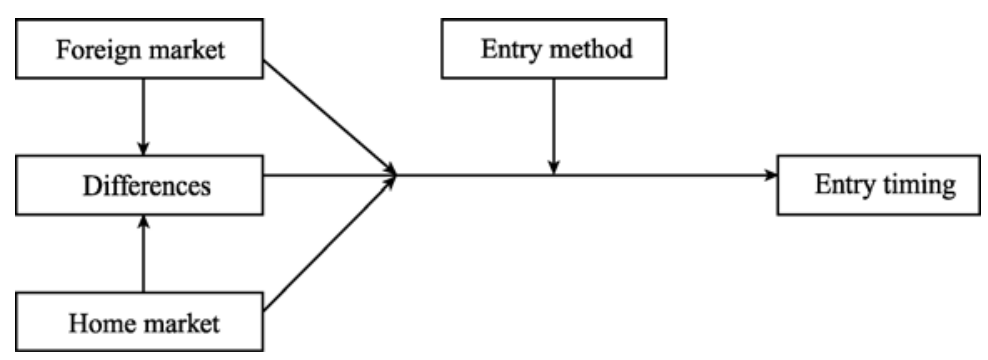

Fig. 1 Relationship between Foreign Market Entry Timing, Entry Method, and Choice of Foreign Market

As shown in Fig 1, the entry timing, entry method and choice of foreign market are three correlated key factors regarding to big retailers' initial internationalization. Among them, the entry timing, as an important turning point of business strategy, is determined based on consideration of the conditions of both home and foreign markets, and entry method. In particular, the conditions of home and foreign markets, the cultural and geographical differences between these markets, can significantly influence the entry timing decision of big retailers' initial internationalization.

\subsection{Influence of the Conditions of Home Market on the Entry Timing}

According to the theory of motivation for internationalization, the conditions of home market will influence retailers' internationalization decision. For example, limited economical growth and fierce competition in the domestic market may compel retailers to go abroad to find more opportunities and resources. In contrast, a promising home market will significantly reduce retailers' motives for going internalization or slowdown their internationalization progress.

Meanwhile, the home market still serves as the base camp for most retailers, and determines retailers' capability to internationalize. A large home market with high purchasing power will enable retailers to accumulate sufficient resources to enter the international market, and vice versa (Bell et al., 2003; Spence, 2003).

We therefore hypothesize that:

H1 The conditions of the home market influence the entry timing of big retailers' initial internationalization (A large home market scale, high purchasing 
power, and low growth will accelerate retailers' internationalization).

\subsection{Influence of the Condition of Foreign Market on the Timing of Entry}

\subsubsection{The Economic Conditions}

As discussed earlier, the theory of motivation for internationalization assumes that the economic conditions in foreign markets have pulling effects on the entry of big retailers into these markets.

The main purpose of a firm's international expansion is to grasp more markets and provide more consumers with goods and services. Naturally, firms will choose to enter the most attractive markets, as these markets can provide them with more growth opportunities (Dunning, 1992). Terpstra and Yu (1988) found that market size is the most important factor influencing U.S. advertising agencies' target market choice. However, Clark and Pugh (2001) found that the income (GDP per capita) rather than size (GDP) of a foreign market is the most important factor affecting British companies' internationalization decision. Furthermore, Rothaermel, Kotha and Steensma (2006) pointed out that high income of a foreign market would strengthen its attractiveness to U.S. firms, and reduce its risks and negative effects caused by the cultural and geographical distance. In addition, the growth prospect and environment for investment in a foreign market also affect firms' entry decision. Hennart and Park (1994) found that the entry of Japanese firms into the U.S. market is motivated principally by the growth prospect. As to retailers, entering the international market needs a substantial amount of investment. Luo (1998) found that the environment for investment in the target market has a significant effect on a retailer's initial internationalization decision. Hence, we hypothesize that:

H2 The conditions of a foreign market influence the entry timing of big retailers' initial internationalization (a large market scale, big purchasing power, fast growth, and favorable environment of investment will accelerate big retailers' internationalization.)

\subsubsection{Degree of Competition in the Foreign Markets}

In markets characterized by high uncertainty and risks, firms are influenced by what other firms in their industry do (Casson, 1987; Porter, 1991). Therefore, a retailer's internationalization decision will be affected by their competitors' behaviors, i.e., the presence of prior entries (Gaba et al., 2002). These effects are significant for two reasons. First, if they are unable to assess the effects of certain decisions, firms usually use the behavior of other firms as justification for their own. When many firms are observed as investing in an overseas market, the 
non-entrants will infer that such entry is profitable, and the earlier they enter, the faster they will gain profits. Second, the followers usually fear that the opportunities may vanish quickly, or the first movers may put up barriers high enough to deter subsequent entries (Porter, 1991). Therefore, the first entry of a firm into a foreign market will be thought as a sign of benefit by other firms, and the later movers will take measures rapidly to get such an opportunity. Therefore, we hypothesize that:

H3 The degree of competition in foreign markets will influence the entry timing of big retailers' initial internationalization (The presence of rival retailers in the foreign market will accelerate other retailers' entry).

3.3 Influence of the Difference between Domestic and Foreign Market on the Timing of Entry

\subsubsection{Cultural Differences}

The existing literature about the effects of culture differences on a firm's internationalization shows that cultural differences between the domestic and foreign market is usually considered, and the differences are defined as cultural distance. According to the organizational learning theory, a firm's internationalization is a stepwise progress, and it will first enter markets with small cultural distance. Much empirical research has confirmed the conclusion (e.g., Bilkey and Tesar, 1977; Hadjikhani, 1997), while the other research has failed to find evidence proving the effect of cultural distance on foreign market entry (e.g., Benito and Grispsrud, 1992; Oviatt and McDougal, 1997; Mitra and Golder, 2002).

Some researchers argued that cultural differences between home market and target foreign market might influence the internationalizing firm's brand strategy, product innovation, and marketing policy. When a firm is operating in a foreign market with completely difference culture, it has to adjust its strategies and policies accordingly and suffer the additional cost and risk (Mitra and Golder, 2002). Just for this reason, many firms usually choose to enter markets with smaller cultural distance from their home market. Thus,

H4 The cultural differences between domestic and foreign markets influence the entry timing of big retailers' internationalization. (Smaller cultural difference will accelerate such an entry).

\subsubsection{Geographical Distance}

Geographical distance has been found exerting a significant influence on firms' internationalization decision. Sricastava and Green (1986) asserted that 
geographical distance has a highly significant impact on trade intensity between countries. Clark and Pugh (2001) investigated British firms' target market selections and found that the first three countries British firms entered were significantly closer than countries they entered subsequently in terms of geographical distance. They suggested that operating in geographically close countries could bring down both economical and managerial costs. Although there seems to be strong support for the concept that firms internationalize their operations first into nearby markets, Terpstra and Yu (1988) failed to find evidence supporting this assumption. Their results suggested that geographical distance does not have a significant influence on the U.S. advertising agencies' internationalization.

As to retailers, the control for risk, managerial and transportation cost are important influencing factors of internationalization strategy. Therefore, retailers are more inclined to enter nearby markets during their internationalization. First, the environment in these markets is usually similar to their home market in terms of language, culture, business practice, and has therefore smaller operation risk. Second, it is less costly to operate in nearby countries than in countries with a greater geographical distance.

So, we hypothesize that:

H5 The geographical distance between the domestic and foreign markets influences the entry timing of big retailers' internationalization (Small geographical distance will accelerate big retailers' internationalization process).

\subsection{Influence of Entry Mode on the Entry Timing}

Entry timing and entry mode are two interrelated important decisions during a firm's internationalization (Mascarenhas, 1997; Madhok, 1997). The entry timing into a target market is necessarily affected by entry mode choice.

This paper classifies the entry mode into two types, namely setting up new subsidiaries directly versus acquiring or cooperating with local firms. If a firm decides to enter a foreign market by setting up new subsidiaries, it will face more resource commitments and higher risks than entering that foreign market by acquiring or cooperating with local firms. Meanwhile, from the entry timing perspective, it appears that an early entry into a foreign market is also associated with a higher level of risk and uncertainty, which requires a firm to act quickly. Due to this uncertainty, choosing to cooperate with or acquire local retailing firms is more beneficial to firms that go for internationalization.

H6 The entry mode influences the timing of big retailers' initial internationalization (acquiring or cooperating with local firms will accelerate big retailers' internationalization process). 


\section{Methods}

\subsection{Measurement}

\subsubsection{Dependent Variables}

The dependent variable of this research is the entry timing of big retailers' initial internationalization, and it is measured by the actual time interval $\mathrm{T}$ (in years) between the founding of big retailers and their first entering into foreign market.

\subsubsection{Independent Variables}

\subsubsection{The Economic Conditions of Home Market}

There are two dimensions to measure the conditions of home market, the current situations, and developing prospects. The current situations include market scale and purchasing power, while the developing prospects are the growth rate of these two aspects.

In this research, we used the GDP of home market (GDPO, in million dollars) at the year when a retailer first went to a foreign market to measure the home market scale, and GDP per capita of home market ( $P G D P O$, in dollars) at the same year to measure the home purchasing power. The developing prospects of home market were measured by the growth rate of GDP and GDP per capita $(G G D P, G P G D P)$. All the measurements were adjusted by the dollar price index in 1995.

\subsubsection{The Economic Conditions of Foreign Market}

Similarly, the current situation and developing prospects were used to measure the conditions of a foreign market. The current situation of foreign market included the whole market scale, the purchasing power and the investing environment, while the developing prospects were the growth rate of these three aspects.

In this article, we used the GDP of the foreign market $(G D P F$, in million dollars) at the year when a retailer first enters to measure the foreign market scale, and the GDP per capita of the foreign market ( $P G D P F$, in dollars) at the same year to measure the foreign purchasing power. As to the investment environment of the foreign market, it refers to a series of factors, such as the foreign country's economical and political risk, its government's attitude and policy to the foreign investment, etc. To summarize, we used the amount of foreign direct investment (FDIF, in million dollars) at the selected year to measure a country's 
environment of investment. The more FDI in a country implies a better environment for investment. The developing prospects of foreign market were measured by the growth rate of GDP, GDP per capita and FDI (GGDPF, $G P G D P F$, and $G F D I F)$. All the measurements were adjusted by the dollar price index in 1995.

At last, we used the number of big international retailers that have already entered the target market (NUMB) to measure the international competence. The bigger the number of big international retailers in a certain market, the fiercer the competition in the market.

\subsubsection{Cultural Differences between Home and Foreign Markets}

Cultural differences (CULD) were measured based on Kogut and Singh's (1988) composite index and Hofstede's (1980) four cultural dimensions. ${ }^{1}$ Geographical distance $(G E O D)$ is measured as the air distances between different countries' capitals (Geir and Gabriel, 2005).

\subsubsection{The Entry Mode of Big Retailers}

In our search, we used a dummy variable to represent the entry mode of big retailers $(E M O D E)$. The entry mode falls into two categories as setting up new subsidiaries $(E M O D E=1)$, and acquiring or cooperating with local firms $(E M O D E=0)$.

\subsection{Proportional Hazard Model}

The first foreign market entry of big retailer is a time-based binary event, and the probability of entry changes over time as a function of time-varying independent variables. This time-based phenomenon is modeled best by the hazard model (Cox, 1972).

In this article, we model the probability of big retailers' first foreign market entry as a function of a baseline hazard function and independent variables. The baseline hazard function specifies the probability of entry given that no entry has

\footnotetext{
1 The culture of countries is divided into four dimensions by Hofstede, namely the power distance, individualism versus collectivism, uncertainty avoidance and masculinity versus femininity. Based on these four dimensions, Kogut and Singh calculated the cultural distance between different countries with the following formula: $C U L D_{i j}=\left(\sum_{i=1}^{4}\left(I_{i j}-I_{i u}\right)^{2} / V_{i}\right) / 4$, where $I_{i j}$ is country $j$ 's $i^{\text {th }}$ cultural dimension index, and $V_{i}$ the variance of the $i^{\text {th }}$ cultural dimension.
} 
occurred up to time $t$ and the independent variables modify the probability of the baseline hazard function.

If the variable $T$ is a random variable representing the time interval between the founding of a retailer and its first foreign market entry, the distribution function of $T$ for no entry after $t$ years (commonly referred to as the survival function) is written as

$$
S(t)=\operatorname{Pr}(T \geqslant t),
$$

where $S(t)$ is the survival function of $T$, and $\operatorname{Pr}$ the probability of no entry up to time $t$.

We can also specify the distribution of $T$ with its hazard function. The hazard function $h(t)$ specifies the instantaneous entry probability at the time $t$, and can be expressed as:

$$
h(t)=\lim _{\Delta t \rightarrow 0} \frac{\operatorname{Pr}(t \leqslant T<t+\Delta t)}{\Delta t}=\frac{f(t)}{S(t)},
$$

where $f(t)$ is the probability density function of $T$.

In Formula (2), we adopt Cox's (1972) proportional hazard model for two reasons: First, it is not constrained by a particular distribution for the baseline hazard function; therefore, it is more robust than other hazard models. Second, it enables us to add the time-varying independent variables into the model. Therefore, the hazard function $h(t)$ of the big retailers' first foreign market entry can be expressed as:

$$
h_{i j}(t)=h\left(t ; z_{i j t}\right)=h_{0}(t) \exp \left(z_{i j t} \beta\right),
$$

where $h_{0}(t)$ is an unspecified baseline hazard function; $Z_{i j t}$ the vector of independent variables for the $i^{\text {th }}$ retailer first entered the $j^{\text {th }}$ country at the time $t$; and $\beta$ the vector of parameters.

\subsection{Sample and Data}

The sample in our research is cited from Deloitte's (2006) statistics on the global top 250 retailers in 2005. As shown, 141 retailers out of the 250 have entered international markets. Then, after months of searching the Answers.com and Hoover database of company historical information and looking through the retailers' official websites, we gathered the information on 71 retailers' founding time, entry timing, target market choice and entry mode during their initial internationalization. After that, we collected the macro data of different country markets. Because the macro data could only be traced back to 1974, we had to eliminate 15 retailers in our sample, which had entered international market before 1974. Our final sample consisted of 56 retailers, and they all came from Europe Union (EU) and the U.S. The distribution of sample retailers by country 
is as follows:

Table 1 Distribution of Retailers by Country

\begin{tabular}{lcclcc}
\hline Country & Big retailers & $\%$ & \multicolumn{1}{c}{ Country } & Big retailers & $\%$ \\
\hline Belgium & 1 & $1.79 \%$ & Italy & 1 & $1.79 \%$ \\
Denmark & 1 & $1.79 \%$ & Netherlands & 1 & $1.79 \%$ \\
Finland & 2 & $3.57 \%$ & Portugal & 2 & $3.57 \%$ \\
France & 4 & $7.14 \%$ & Spain & 3 & $5.36 \%$ \\
Germany & 6 & $10.71 \%$ & United Kingdom & 12 & $21.43 \%$ \\
Ireland & 1 & $1.79 \%$ & United States & 22 & $39.29 \%$ \\
\hline
\end{tabular}

All the macro economic data in our research, such as the GDP, GDP per capita and the growth rate of the home and foreign country were taken from the UN database.

\section{Empirical Results}

\subsection{Descriptive Statistics}

Fig. 2 shows that most of the 56 big retailers in our research $(67.9 \%)$, chose to start their internationalization during the 1990s.

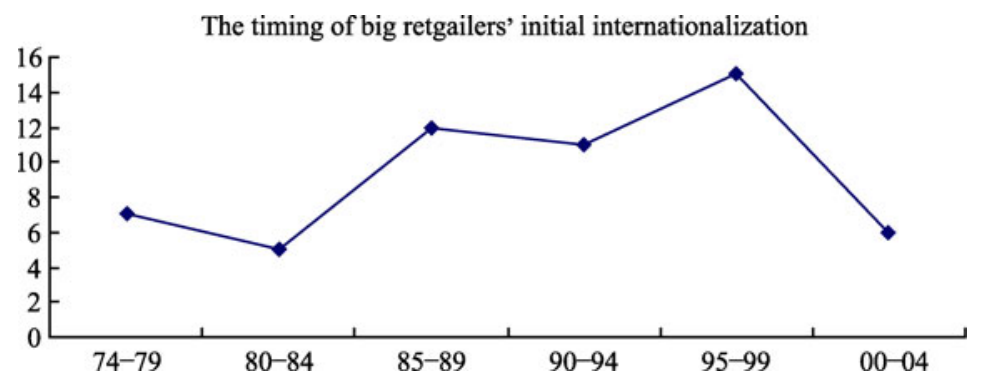

Fig. 2 The Distribution of Entry Timing of Big Retailers' Initial Internationalization

Table 2 shows that, the target market choice of EU retailers were much more divergent than their U.S. peers. The $34 \mathrm{EU}$ big retailers chose to enter 18 different country markets, while the 22 U.S. big retailers only entered 6 countries (11 of them entered Canada). For the initial internationalization timing, the EU big retailers tend to wait for a long time (79 years at average) before their entry into international market, whereas the time for the U.S. big retailers was less than 22 years. For the entry mode of the initial internationalization, the $16 \mathrm{EU}$ big 
retailers chose to set up new subsidiaries and $17 \mathrm{EU}$ big retailers chose to acquire or cooperate with local firms. By comparison, U.S. big retailers seem to prefer setting up new subsidiaries: among the 22 U.S. retailers, 18 chose to set up new subsidiaries, and only 4 choose to acquire or cooperate with local firms.

Table 2 Descriptive Statistics on the Target Market, Entry Timing, and Entry Mode

\begin{tabular}{lcclcc}
\hline Target market & EU retailers & U.S. retailers & Target market & EU retailers & U.S. retailers \\
\hline Bahrain & 1 & 0 & Austria & 2 & 0 \\
Brazil & 1 & 0 & Netherlands & 2 & 0 \\
Estonia & 1 & 0 & Portugal & 2 & 0 \\
Germany & 1 & 0 & Singapore & 0 & 2 \\
Hungary & 1 & 0 & France & 3 & 0 \\
Japan & 0 & 1 & Ireland & 3 & 0 \\
Kuwait & 1 & 0 & Mexico & 0 & 4 \\
Poland & 1 & 0 & Spain & 5 & 0 \\
Puerto Rico & 0 & 1 & United Kingdom & 2 & 3 \\
Sweden & 1 & 0 & United States & 5 & 0 \\
Switzerland & 1 & 0 & Canada & 1 & 11 \\
\hline
\end{tabular}

Entry timing: EU retailers average 78.85 years, U.S. retailers average 21.91 years

Entry mode (setting up subsidiaries vs. acquiring or cooperating with local firms): EU retailers (16 vs. 17), U.S. retailers (18 vs. 4)

\subsection{Empirical Results of the Proportional Hazard Model}

\subsubsection{Comparison between EU and U.S. Retailers' Initial Internationalization} Timing

First, we compared the EU and U.S. big retailers' initial internationalization timing. Fig. 3 shows that there is a visible difference in term of survival function between the two: The curve of U.S. retailers' survival function is steep, while the curve of EU retailers' survival function is quite smooth. This means that, the U.S. big retailers entered the international market in a mass within a short time, while the EU big retailers entered the international market in a dispersed way and over a longer period of time.

Then, we used Mantel and Cox's Log Rank to test the difference between EU and U.S. retailers' survival function. The result shows that the difference is quite significant $\left(\chi^{2}=23.721, p=0.000\right)$. 


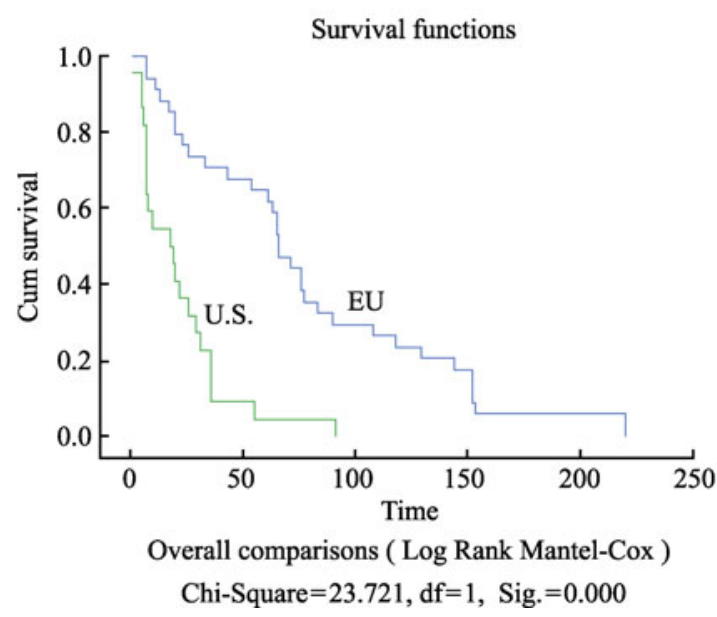

Fig. 3 Comparison of the Survival Function between EU and U.S. Big Retailers' Initial Internationalization Timing

\subsubsection{Empirical Results of Proportional Hazard Model for EU and U.S. Retailers}

We estimated the Hazard Model (3) with the semi-parametric partial likelihood method proposed by Cox (1972), and the data collected from the EU and U.S. big retailers' initial internationalization. The results are presented in Table 3.

Table 3 shows that the proportional hazard models fit quite well both for the EU and U.S. big retailers' initial internationalization.

The results of EU proportional hazard model show that there are 6 factors (belonging to 4 different categories) influencing EU big retailers' entry timing during their initial internationalization, including the conditions of home market such as the purchasing power (GDP per capita of home market, $P G D P O$ ); the conditions of foreign market: market scale (GDP of foreign market, GDPF), developing prospect (GDP growth rate of foreign market, GGDPF), and investing environment $(F D I F)$; the difference between the home and foreign market (the cultural distance, $C U L D$ ); and the entry mode of big retailers $(E M O D E)$.

The results of U.S. proportional hazard model show that there are 12 factors (belonging to 4 different categories) influencing the U.S. big retailers' entry timing during their initial internationalization, including the conditions of their home market: market scale (GDP of home market, GDPO), purchasing power (GDP per capita of home market, $P G D P O$ ), and their growth rate (GGDPO, $G P G D P O$ ); the conditions of foreign market: purchasing power (GDP per capita of foreign markets, $P G D P F)$, its growth rate $(G P G D P F)$, the investment environment $(F D I F)$ and its growth rate $(G F D I F)$; the differences between the 
home and foreign markets: the cultural distance (CULD), and the geographical distance $(G E O D)$; and the entry mode of big retailers $(E M O D E)$.

Table 3 Results of Proportional Hazard Model for EU and U.S. Big Retailers' Initial Internationalization

\begin{tabular}{|c|c|c|c|c|c|c|}
\hline \multirow{2}{*}{$\begin{array}{l}\text { Independent } \\
\text { variables }\end{array}$} & \multicolumn{3}{|c|}{ Model for EU } & \multicolumn{3}{|c|}{ Model for U.S. } \\
\hline & $B$ & Wald & Sig. & $B$ & Wald & Sig. \\
\hline$G D P O$ & -0.001 & 1.419 & 0.234 & 0.052 & 4.940 & $0.026^{*}$ \\
\hline$G G D P O$ & -24.726 & 1.734 & 0.188 & 664.271 & 4.366 & $0.037^{*}$ \\
\hline$P G D P O$ & 0.000 & 5.193 & $0.023^{*}$ & -0.014 & 5.737 & $0.017^{*}$ \\
\hline$G P G D P O$ & 4.113 & 1.060 & 0.303 & -785.005 & 4.186 & $0.041^{*}$ \\
\hline$G D P F$ & -0.001 & 4.023 & $0.045^{*}$ & 0.003 & 1.277 & 0.258 \\
\hline$G G D P F$ & 45.144 & 5.081 & $0.024^{*}$ & 68.614 & 0.754 & 0.385 \\
\hline$P G D P F$ & 0.000 & 0.579 & 0.447 & 0.002 & 7.929 & $0.005^{* *}$ \\
\hline$G P G D P F$ & -6.683 & 2.861 & 0.091 & 21.829 & 3.015 & $0.082^{*}$ \\
\hline FDIF & 0.000 & 4.061 & $0.044^{*}$ & 0.002 & 7.492 & $0.006^{* *}$ \\
\hline GFDIF & -0.565 & 1.512 & 0.219 & 6.178 & 5.167 & $0.023^{*}$ \\
\hline$N U M B$ & 0.379 & 1.944 & 0.163 & 3.984 & 7.179 & $0.007^{* *}$ \\
\hline GEOD & 0.000 & 0.049 & 0.825 & -0.003 & 6.654 & $0.010^{*}$ \\
\hline$C U L D$ & -1.120 & 6.858 & $0.009^{* *}$ & 19.339 & 7.180 & $0.007^{* *}$ \\
\hline$E M O D E$ & 1.707 & 5.354 & $0.021^{*}$ & -24.634 & 6.158 & $0.013^{*}$ \\
\hline
\end{tabular}

Model for EU: -2 Log Likelihood $=120.378$, Chi-square $=35.682, \mathrm{df}=14, \mathrm{Sig} .=0.001$

Model for U.S.: $-2 \log$ Likelihood $=45.970$, Chi-square $=44.012, \mathrm{df}=14$, Sig. $=0.000$

Note: $*$, and $* *$ denote statistically significant at the $5 \%$ and $1 \%$ levels, respectively.

Overall, these two models support the framework of the big retailers' initial internationalization decision. Both of the EU and U.S. proportional hazard model results show that during the big retailers' initial internationalization, the conditions of home market and foreign markets, the differences between home and foreign market, and the entry mode can all significantly influence the entry timing.

Table 3 also shows the specific effects that the independent variables have on the entry timing of big retailers' initial internationalization. If a variable's parameter is positive, it will encourage big retailers to internationalize, or deter them from going abroad if the parameter is negative. The above empirical results support our hypotheses.

Specifically, the economic conditions of home market have significant "pushing" effects on big retailers' initial internationalization. Strong purchasing 
power $(P G D P O)$ encourages EU big retailers to enter international markets. While large home market scale $(G D P O)$ encourages U.S. big retailers to internationalize. However, the fast growth in home market purchasing power $(G P G D P)$ deters U.S. big retailers from expanding to foreign markets.

The economic conditions of the target market have significant "pulling" effects on sample retailers' initial internationalization. Promising economic prospects and profitable investing environment of a target market (GGDPF, $F D I F$ ) encourage EU big retailers to enter the market. While strong purchasing power and its growth rate $(P G D P F, G P G D P F)$, profitable investing environment, and prospect $(F D I F, G F D I F)$ of target market foster U.S. big retailers to internationalize earlier. Moreover, the international competition also influences big retailers' entry timing: if there are a lot of big retailers that have already entered a target market, U.S. retailers will be compelled to enter that market more quickly.

The differences between home and target market hamper big retailers' progress of internationalization. Great cultural difference (CULD) deters the EU big retailers from entering into some foreign markets, while great geographical distance $(G E O D)$ is considered as a main obstacle to the internationalization of many U.S. big retailers.

The entry mode $(E M O D \mathrm{E})$ also affects big retailers' internationalization progress. As to the U.S. retailers, if a retailer chooses to enter a foreign market by setting up new subsidiaries, it usually intends to enter that market later than the retailers that use the entry mode of acquiring or cooperating.

However, we also found that some hypotheses were not supported by data. The empirical results show that EU big retailers chose to firstly enter country with comparatively smaller market scale, and prefer high-risk entry mode, while U.S. big retailers' internationalization is fostered by fast home GDP growth but hampered by strong home purchasing power. These findings are inconsistent with our hypotheses, and therefore need to be further examined in future studies.

\section{Conclusion and Discussion}

\subsection{Findings}

(1) This empirical research tested the proposed framework model of big retailers' initial internationalization. Our results show that big retailers' entry timing decision of initial internationalization is made based on consideration conditions of different markets and entry methods.

(2) The economic conditions of the home and foreign markets significantly influence big retailers' initial entry timing. The conditions of the home market have a pulling effect on the big retailers' initial internationalization. A large home market scale and strong purchasing power can accelerate big retailers' 
internationalization progress, while rapid economic growth can deter it. The conditions of foreign markets have a pushing effect on big retailers' initial internationalization. Large foreign market scales, strong purchasing power, fast growth, and favorable environment of investment will accelerate big retailers' internationalization process. In addition, the degree of international competition in foreign markets also has a pushing effect on big retailers' initial internationalization. The presence of their rivals in a target foreign market will accelerate retailers' entry into the market.

(3) The cultural and geographical distance between the home and foreign markets can hamper big retailers' early entry. Generally speaking, big retailers usually choose to enter first the markets they are familiar with.

(4) The entry mode influences the timing of big retailers' initial internationalization. Acquiring or cooperating with local firms, which are associated with lower levels of risk, will accelerate big retailers' internationalization process.

(5) There are many obvious differences between EU and U.S. big retailers both in their internationalization timing and influencing factors for internationalization. First, for the initial internationalization timing, EU big retailers tend to wait for a longer time (an average of nearly 79 years), while the time for U.S. big retailers are comparatively shorter (less than 22 years). In addition, EU retailers face fewer factors affecting their entry timing decisions, including the purchasing power of the home market, the foreign market scale, foreign market developing prospect, foreign investing environment, cultural distance, and the entry mode. However, the U.S. retailers face more factors. Except foreign market scale and its growth rate, 12 out of the 14 influencing factors for retailer internationalization identified in this article significantly affect U.S. retailers' entry timing decisions.

\subsection{Implications for Chinese Retailers' Internationalization}

After China's entering into the WTO, there have been many dramatic changes in China's retailing industry. Many big international retailers have rushed into the Chinese market, and the competition is becoming increasingly fierce. However, by relocating their resources and learning in the competition, Chinese retailers have made a great progress in their scale and operation efficiency. At present, an increasing number of Chinese big retailers have begun to take international strategy into consideration. In doing so, Chinese managers have to firstly solve many related problems, such as when, where and how to enter foreign markets.

\subsubsection{The Decision Framework for Chinese Big Retailers' Initial Internationalization}

The empirical results in this article show that, there are three inter-correlated 
questions in the retailers' initial internationalization, namely the entry timing, target market choice and entry mode. Among them, the retailers' entry timing decision is made on the basis of a comprehensive consideration on the conditions of the home and foreign markets, and different entry modes. Chinese retailers may follow this framework, and carefully choose their entry timing, market choice and entry mode after a comprehensive analysis of domestic market conditions, target market conditions, and the cultural and geographical differences between home market and the target foreign market.

\subsubsection{Suggestions for China's Big Retailers Initial Internationalization Decision}

Although Chinese retailers have made a great progress in recent decades, they are still facing a lot of problems in their internationalization road, both in scale and operation efficiency. Especially in terms of internationalization, Chinese retailers still fall far behind their EU and U.S. peers. Now, more Chinese big retailers just began to consider operating in international market and most of these operations belong to the initial internationalization decision. Based on the empirical results, we propose several suggestions to Chinese big retailers:

First, our empirical results find that slow development in the home market would accelerate retailers to internationalize. However, China's economy is developing at a high speed, and there are still many small and medium sized cities under development. Therefore, the market potential is big enough for Chinese retailers to develop in the domestic market.

Second, our results show that if the target market is characterized by a large scale, rapid growth, favorable investing environment, small cultural and geographical distance, and little competition, it will encourage more foreign retailers to enter. Therefore, for Chinese retailers who are considering entering international market, these requirements can serve as the standards in choosing target markets. For example, they are encouraged to focus on nearby emerging economies with similar culture and rapid economic growth, such as Singapore, Thailand, and Malaysia, etc.

Lastly, our results also suggest that during the retailers' initial internationalization, there is a close relationship between the entry timing and entry mode. Learning from the U.S. experience, the entry mode with low level of risks will accelerate retailers' internationalization process. In reality, Chinese retailers undergoing their early internationalization commonly suffer from a deficiency of financial and managerial abilities. Therefore, they should pay more attention to the entry mode characterized with low risks, such as setting up joint ventures or cooperating with local retailers in the target market. In this way, Chinese retailers can reduce their resource commitment and cooperate with local retailers who are familiar with local resources, market conditions, and 
government's policy.

\subsection{Limitations and Future Research}

This article is just a trial empirical research on big retailers' initial internationalization timing decision. There are several important limitations: First, this article merely focuses on big retailers, neglecting small and medium sized retailers. Second, we only analyze retailers that have conducted internationalization strategies successfully, neglecting those failed ones. Moreover, most of the data used in our research were drawn from the macro level, neglecting the micro factors such as the retailers' resources and management which might have significant influence on retailers' internationalization decisions.

There are two directions for the future research. One is to expand the research scope and further analyze the small and medium sized retailers' probabilities and experience in internationalization. The other is to study retailers' internationalization from a micro perspective, and analyze the influence of retailers' resources and management on their internationalization decisions.

Acknowledgements This work is supported by the National Social Science Foundation of China (No. 05BJY082).

\section{References}

Agarwal S, Ramaswami S N (1992). Choice of foreign market entry mode: Impact of ownership, location and internationalization factors. Journal of International Business Studies, 23(1): 1-27

Anderson E, Gatignon H (1986). Mode of entry: A transaction cost analysis and propositions. Journal of International Business Studies, 17(3): 1-26

Barkema H G, Vermeulen F (1998). International expansion through start-up or acquisition: A learning perspective. Academy of Management Journal, 41(1): 426-442

Barkema H G, Bell J H, Pennings J M (1996). Foreign entry, cultural barriers, and learning. Strategic Management Journal, 17(2): 151-166

Bell J (1997). A comparative study of the export problems of small computer software exporters in Finland, Ireland and Norway. International Business Review, 6(6): 585-604

Bell J, McNaughton R, Young S, Crick D (2003). Towards an integrative model of firm internationalization. Journal of International Entrepreneurship, 1(1): 339-362

Benito G R, Gripsrud G (1992). The expansion of foreign direct investment: Discrete rational location choices or a culture learning process? Journal of International Business Studies, 23(3): 461-476

Bilkey W J, Tesar G (1977). The export behavior of small-sized Wisconsin manufacturing firms. Journal of International Business Studies, 8(1): 93-98

Buckley P J, Casson M (1981). The optimal timing of a foreign direct investment. The Economic Journal, 91: 75-87 
Casson M (1987). The Firm and the Market: Studies on Multinational Enterprises and the Scope of Firm. Cambridge, MA: MIT Press

Chain Store Age (1997). Retailing's great global gold rush. Global Retailing Supplement, 3-11

Timothy C, Pugh D S (2001). Foreign country priorities in the internationalization process: A measure and an exploratory test on British firms. International Business Review, 10(3): 285-303

Coviello N (2006). The network dynamics of international new ventures. Journal of International Business Studies, 37(5): 713-731

Cox D R (1972). Regression models and life tables. Journal of the Royal Statistics Society, 34: $187-220$

Davidson W H (1980). The location determinants of direct investment activity: Country characteristics and experience effects. Journal of International Business Studies, 11(2): 9-22

Deloitte Touche Tohmatsu (2006). Global Powers of Retailing. www.deloitte.com

Diericks L, Cool K, Barney J B (1989). Asset stock accumulation and sustainability of competitive advantage. Management Science, 35(12): 1504-1514

Douglas S P, Craig C S (1995). Global Marketing Strategy. New York: McGraw-Hill

Dunning J H (1973). The determinants of international production. Oxford Economic Papers, 25(3): 289-336

Dunning J H (1988). The eclectic paradigm of international production: A restatement and some possible extensions. Journal of International Business Studies, 19(1): 1-31

Dunning J H (1992) Multinational Enterprises and the Global Economy. Reading, MA: Aaaison-Wesley

Ekeledo I, Sivakumar K (1998). Foreign market entry mode choice: A modified transaction cost analysis approach. Journal of Marketing, 57(3): 19-38

Gaba V, Pan Y G, Ungson G R (2002). Timing of entry in international market: An empirical study of U.S. fortune 500 firms in China. Journal of International Business Studies, 33(1): $39-55$

Global Production Networks (GPN) (2003). The internationalization/globalization of retailing: Towards a geographical research agenda? GPN working paper 8

Hadjikhani A (1997). A note on the criticisms against the internationalization process model. Management International Review, 37(2): 43-66

Hennart J F, Young R P (1994). Location, governance, and strategic determinants of Japanese manufacturing investments in United States. Strategic Management Journal, 15: 419-436

Hill C W, Hwang P Kim W C (1990). An eclectic theory of the choice of international entry mode. Strategy Management Journal, 11: 117-128

Hofstede G (1980). Culture's Consequence: International Difference in Work-Related Values. Beverly Hills, CA: Sage Publications

Jones G K, Coviello N E (2005). Internationalization: Conceptualizing an entrepreneurial process of behavior in time. Journal of International Business Studies, 36(3): 284-303

Kerin R P, Varadarajan P R, Peterson R A (1992). First-mover advantage: A synthesis, conceptual framework, and research propositions. Journal of Marketing, 56: 33-52

Kim W C, Hwang P (1992). Global strategy and multinationals' entry mode choice. Journal of International Business Studies, 23(1): 29-53

Kogut B, Singh H (1988). The effect of national culture on the choice of entry mode. Journal of International Business Studies, 19: 411-432

Leonidou LC, Katsikeas C S (1996). The export development process: An integrative review of empirical models. Journal of International Business Studies, 27(3): 517-551

Lieberman M B, Montgomery D B (1988). Fist-mover advantage. Strategy Management 
Journal, 19: 41-58

Lieberman M B, Montgomery D B (1998). First mover (dis)advantages: Retrospective and link with the resource-based view. Strategy Management Journal, 19: 1111-1125

Lippman S A, Rumelt R P (1982). An analysis of interfirm differences in efficiency under competition. Bell Journal of Economics, 13(2): 418-438

Luo Y D (1998). Timing of investment and international expansion performance in China. Journal of International Business Studies, 29(2): 391-408

Madhok A (1997). Cost, value and foreign market entry mode: The transaction and the firm. Strategy Management Journal, 18(1): 39-61

Mascarenha B (1992). Order of entry and performance in international markets. Strategy Management Journal, 13: 531-543

McGoldrick P J, Davies G (1995). International Retailing: Trends and Strategies. London: Pitman Publishing

Mitra D, Golder P N (2002). Whose culture matters? Near-market knowledge and its impact on foreign market entry timing. Journal of Marketing Research, 39: 350-365

Moen O, Morten G, Endresen I (2004). Internationalization of small computer software firms: Entry forms and market selection. European Journal of Marketing, 38: 1236-1251

Ojala A, Tyrvainen P (2007). Market entry and priority of small and medium-sized enterprises in the software industry: An empirical analysis of cultural distance, geographical distance and market size. Journal of International Marketing, 15(3): 123-149

Oviatt B M, McDougal P P (1997). Challenges for internationalization process theory: The case of international new ventures. Management International Review, 37(2): 85-99

Porter M E (1991). Towards a dynamic theory of strategy. Strategic Management Journal, 12: 95-117

Rothaermel F T, Kotha S, Steensma H K (2006). International market entry by U.S. internet firms: An empirical analysis of country risk, national culture, and market size. Journal of Management, 32(1): 56-82

Sivakumar K (2002). Simultaneous determination of entry timing and involvement level: An optimization model for international marketing. International Marketing Review, 19(1): 21-38

Spence M (2003). International strategy formation in small Canadian high-technology companies: A case study approach. Journal of International Entrepreneurship, 1(3): 277-296

Sricastava R K, Green R T (1986). Determinants of bilateral trade flows. Journal of Business, 59(4): 623-640

Szymanski D M, Troy L C, Bharadwaj S G (1995). Order of entry and business performance: An empirical synthesis and reexamination. Journal of Marketing, 59: 17-33

Terpstra V, Sarathy R (1994). International Marketing, $6^{\text {th }}$ ed. Fort Worth, TX: Dryden Press

Terpstra V, Yu C M (1988). Determinants of foreign investment of U.S. advertising agencies. Journal of International Business Studies, 19(1): 33-46

Woodcock P C, Beamish P W, Makino S (1994). Ownership-based entry mode strategies and international performance. Journal of International Business Studies, 25(2): 253-273

Wrigley N, Lowe M (2002). Reading Retail: A Geographical Perspective on Retailing and Consumption Space. London: Arnold 